\title{
HYPOGLYCAEMIA IN CHILDHOOD
}

\author{
C. B. S. Wood, M.R.C.P., D.C.H. \\ Evelina Children's Hospital of Guy's Hospital, \\ London S.E.1
}

HyPOgLyCAEMIA in children may cause listlessness, inattention, pallor, stupor, convulsions and coma, which may be accompanied by tachycardia and sweating. Such non-specific symptoms as cyanotic attacks, reluctance to feed, irritability, convulsions, jittery limb movements and depression of the Moro reflex may occur in the hypoglycaemic newborn infant. A major part of these clinical patterns arises from the neuroglycopenia which is caused by hypoglycaemia.

Hypoglycaemia has been recognised in childhood for over forty years (Ross and Josephs, 1924) and yet its true incidence in the newborn and older child is still difficult to assess today.

Forty cases occurred amongst children of all ages in a one hundred and thirty bed unit over a twelve year period (McQuarrie, 1954) and twelve neonatal cases were found among six thousand newborn infants (Neligan, Robson and Walton, 1963). The incidence of symptomatic hypoglycaemia has been found to be no less than $6 \%$ among premature infants, and as high as $15 \%$ in infants of birth weight less than the fiftieth percentile for gestational age (Wybregt, Reisner, Patel, Nellhaus and Cornblath, 1964).

Many different methods of blood sugar estimation have been used, and early less specific reduction methods (Folin and Wu 1920; Hagedorn and Jensen, 1923) tended to give higher figures than more specific reduction methods (Somogyi, 1952) and the glucose oxidase method (Marks, 1959). It is therefore difficult to define hypoglycaemia in terms of a blood glucose level. There is little doubt that the threshold for symptoms of neuroglycopenia varies from patient and from time to time. In the newborn a blood glucose level of under $20 \mathrm{mg}$./ $100 \mathrm{ml}$. or even below $10 \mathrm{mg} . / 100 \mathrm{ml}$. may occasionally occur without symptoms, and many older children are not affected unless the level is under $40 \mathrm{mg} . / 100 \mathrm{ml}$.

Endocrine deficiencies causing hypoglycaemia are rare in childhood. Fasting hypoglycaemia was found in $29.3 \%$ of seventy-five cases of hypopituitarism, and hypoglycaemic symptoms occured in $9.7 \%$. In $37.5 \%$ of this series hypoglycaemia followed a glucose load and $66.7 \%$ were sensitive to insulin (Brasel, Wright, Wilkins and Blizzard, 1965). The

\author{
T. P. ManN, M.D., F.R.C.P. \\ Royal Alexandra Hospital for Sick Children, \\ Brighton
}

insulin sensitivity test, and the failure of blood glucose levels to return to normal quickly after insulin are useful screening tests for hypopituitarism especially when combined with measurements of blood growth hormone levels during insulin induced hypoglycaemia. A variety of methods of performing insulin tests is established (Daniel, 1941; Greenblath and Kupperman, 1947; Frazer, Albright and Smith, 1941; Roth, Glick, Yalow and Berson, 1963). Increased insulin sensitivity is also found in several other types of hypoglycaemia.

Isolated growth hormone deficiency in a child associated with some degree of leucine sensitivity and hypoglycaemia has been described (Nadler, Neumann and Gershberg, 1963). In adults isolated ACTH deficiency has been reported to cause hypoglycaemia (Odell, Green and Williams, 1960) but in a child ACTH deficiency existed without hypoglycaemia (Cleveland, Green and Migeon, 1960). Growth hormone studies were not undertaken in these two cases, but in the former the hypoglycaemia responded to steroid replacement. Acute adrenal haemorrhage (Magnusson, 1934), congenital adrenal cortical hyperplasia (White and Sutton, 1951), and chronic adrenal cortical insufficiency (Williams and Robinson, 1956; Geppert, Spencer and Richmond 1950) may all cause hypoglycaemia. Hypoglycaemia has also been observed in cretinism (McQuarrie, 1954).

A child has been reported in whom hypoglycaemia occurred three years before the onset of clinical diabetes mellitus (Lloyd, 1964).

Fasting hypoglycaemia in adults with benign $\beta$-cell pancreatic tumours can be shown to be accompanied by high fasting blood insulin levels (Samols and Marks 1963). Such tumours are rare in children (Francois, Pradon, Sherrer and Ugliengo, 1962; Roxburgh, 1954) and malignant $\beta$-cell tumour even more unusual (Hurez, Bedouelle, Debray, Le Bras and Halle, 1961). In the presence of a $\beta$-cell tumour blood glucose levels may be unusually stable during insulin sensitivity tests (Francois and others, 1962) and yet considerably depressed by tolbutamide and leucine (Samols, 1963; Fajans, Schneider, Schteingart and Conn, 1961). The tolbutamide test may not be a reliable screening test for $\beta$-cell tumours in children (Cunningham, 
1964). A pancreatic $\beta$-cell tumour has been reported in one case of tuberous sclerosis in a young adult who had hypoglycaemia and who had had fits since childhood (Gutman and Leffkowitz, 1959). Pancreatic $\beta$-cell adenomata occured in three members of a family, one of whom also had a parathyroid adenoma (Underwood and Jacobs, 1963).

Hypoglycaemia has been reported in adolescents with adrenal carcinoma (Broster and Patterson, 1948), adrenal fibrosarcoma (Howard, 1955) and retroperitoneal hemangio-pericytoma and in the latter was associated with masculinisation (Howard and Davis, 1959). Hypoglycaemia has also been found in a child with a Wilms tumour (Loutfi, Mehrez, Shahbender and Abdine, 1964). Surgical removal of malignant tumours may result in control of symptoms, but hypoglycaemia may well return when metastases appear. The mechanism of hypoglycaemia in the presence of these tumours is uncertain.

Congenital deficiency of hepatic fructose-1phosphate aldolase and hepatic galactose-1phosphate uridyl transferase occur respectively in fructose intolerance (Levin, Oberholzer, Snodgrass, Stimmler and Wilmers, 1963) and galactosaemia (Woolf, 1962). Both conditions behave genetically as autosomal recessives. Fructose intolerance is to be distinguished from benign fructosuria (Laron, 1961), due to deficiency of hepatic fructokinase. In fructose intolerance ingestion of the sugar or sucrose induces profound hypoglycaemia which may be accompanied by some rise in the blood level of magnesium. The affected infant may collapse and convulse. Vomiting, failure to thrive, hepatosplenomegaly and jaundice are prominent features. In galactosaemia, hypoglycaemia is less likely to occur after ingestion of lactose than after a galactose tolerance test (Komrower, Schwarz, Holzel and Goldberg, 1956). Other features of the illness are failure to thrive, vomiting, hepatic enlargement, jaundice, cataract, proteinuria and aminoaciduria. High blood levels of fructose and galactose are not thought to stimulate insulin production, but it has been suggested that the accumulation of galactose metabolites (Sidbury, 1957) and fructose metabolites within liver cells may inhibit glycolysis.

Hepatomegaly, failure to thrive, fasting hypoglycaemia, insulin sensitivity, acidosis, hyperlipaemia and poor glucagon and adrenaline responses occur in the three varieties of glycogenosis which are due to deficiency of hepatic glucose-6-phosphatase (Hers, 1964), 1-6 amyloglucosidase (Hers, 1964; Illingworth, Cori and Cori, 1956), and hepatic phosphorylase (Hers, 1964). The diagnosis of 1-6 amyloglucosidase deficiency may be made by examining the abnormal absorption spectrum of the abnormal glycogen (limit dextrin) formed in the erythrocytes (Sidbury, Cornblath, Fisher and House, 1961). Glycogen synthetase deficiency, recently identified, is also accompanied by hypoglycaemia (Lewis, SpencerPeet and Stewart, 1963).

Prolonged fasting in children who do not suffer from symptomatic hypoglycaemia may produce lower blood sugar levels than similar fasting in adults (Talbot, Shaw and Moriarty, 1924), and in profound malnutrition, as in kwashiorkor, gross irreversible and fatal hypoglycaemia may occur (Wayburne, 1963). Emery (1947) reports that in coeliac disease fasting may induce sweating but the blood sugar does not fall to hypoglycaemic levels. Two well nourished phenylketonuric children on low phenylalanine diets became hypoglycaemic with neuroglycopenia during a period when dietary intake was probably inadequate. One died and was found to have an oedematous brain and a fatty liver (Dodge, Mancall, Crawford, Knapp and Paine, 1959).

Catastrophic liver necrosis results in hypoglycaemia and has been reported in phosphorus poisoning (McIntosh, 1927) but is rare in infective hepatitis (Tomlinson, 1955). An acute and frequentlye fatal association of hypoglycaemia, fatty viscera and oedematous brain has recently been reported fromo several centres (Elliott, Mann and Nash, 1962 Reye, Morgan and Barail, 1963; McC. Giles, 1965) The aetiology of this fulminating illness is unknown; and an unidentified toxic agent may be responsible. Salicylates have been suspected since it is clear that they may occasionally cause hypoglycaemia (Cotton and Fahlberg, 1964; Limbeck, Ruvalcaba, Samols and Kelley, 1965).

Other chemical agents which may induce hypoglycaemia in childhood include ethyl alcohol (Cummins, 1961; Tolis, 1965) and possibly parathion (Hruban, Schulman, Warner, Dubois, Bunnag and Bunnag, 1963). Poisoning with amanita phalloides results in initial hyperglycaemia, and then hypoglycaemia as hepatic necrosis proceeds (Gaultier, Fournier, Gervais, Frejaville and Prier, 1962). It is of interest that in diabetic adults on tolbutamide, sulphaphenazole provoked hypoglycaemia (Christensen, Hansen and Kristensen, 1963). Calcium disodium versenate has produced hypoglycaemia in adults on insulin zinc (Meltzer, Palmon and Kitchell, 1961), and hypoglycaemia has also occurred during the use of mebanazine in a diabetic adult on insulin (Cooper and Keddie, 1964). In barbiturate addicts administration of glucose may result in considerable reactive hypoglycaemia (Merivale and Hunter, 1954). In adults hypoglycaemia may have occurred during treatment with para-aminosalicylic acid (Ollagnier, Perrin and 
Mirraillet, 1959) and methicillin (Planchu, Bertoye, Piquet and Bertrand, 1963). Tris (hydroxymethyl) aminomethane (THAM) may cause hypoglycaemia in adults and experimental animals (Tarail and Bennett, 1959; Bennett and Tarail, 1961). The clinical situations in which this drug is used in the newborn are in any case sometimes associated with hypoglycaemia. In a young adult diabetic hypoglycaemia was induced by an infusion of lucerne grass which contains manganese (Rubenstein, Levin and Elliott, 1962). In the mysterious and often fatal "vomiting sickness" of Jamaica, fatty liver and hypoglycaemia occur, and the saponins in unripe ackee may be responsible (Hill, 1952; Stuart, Jeliffe and Hill, 1955; Patrick, Jeliffe and Stuart, 1955).

Hypoglycaemia has been reported during the course of certain infections. However, four fatal cases of varicella which were complicated by hypoglycaemia and probably by encephalitis had been given salicylates during their final illness (Mortimer and Lepow, 1962). The association of hypoglycaemia and varicella encephalitis is not invariably fatal (Mann, 1959b; Nader and Leonards, 1965).

Hypoglycaemia has also been reported during measles (Jeannin, 1960).

These varied reports prompt caution in the medication of children and make it essential to consider hypoglycaemia in a wide range of clinical situations including infections and poisoning.

Idiopathic hypoglycaemia is gradually yielding to subdivision, although some cases are not yet classifiable. A group with severe fasting hypoglycaemia, more common in males, and sometimes familial, was found to occur usually before the third year of life, to respond to ACTH and to tend to remission (McQuarrie, 1954; McQuarrie, Ulstrom and Ziegler, 1954). Pancreatic biopsy revealed no $\beta$-cell hyperplasia in this group, and in one sibship $\propto$-cells were deficient.

More recently, other cases thought to be idiopathic have been shown to be due to sensitivity to leucine (Cochrane, Payne, Simpkiss and Woolf, 1956). The leucine sensitivity test has been standardised (Mabry, di George and Auerbach, 1960 a) and the effect is specific for $L$-leucine, intravenous $\mathbf{D}$-leucine and $\propto$-keto-isocaproic acid (Mabry and others $1960 \mathrm{~b}$ ).

L-leucine has some hypoglycaemic effect on normal individuals (di George, Auerbach and Mabry, 1963) and a high blood level of $L$ - leucine is believed to induce hyperinsulinism (di George and Auerbach, 1960) and to cause the hypoglycaemia which occurs in maple syrup urine disease (Menkes, 1964). In the young adult tolbutamide has been found to induce leucine sensitivity (Jarrett and Butterfield, 1964).
A failure of the normal rise in excretion of adrenaline products during insulin-induced hypoglycaemia characterises another group in which $\stackrel{\varrho}{c}$ hypoglycaemia and neuroglycopenia are not accompanied by the tachycardia and sweating of hyperadrenalism (Kinsbourne and Woolf, 1959; Broberger and Zetterstrom, 1961). One case of glycogen synthetase deficiency also showed this biochemical abnor mality (Lewis and others 1963).

For many years an association has been noted between fasting ketosis and idiopathic non-endocrine hypoglycaemia, which has occasionally been complicated by haematemesis (Ross and Josephs, 1924; Rector and Jennings 1937; Mann 1959 a). A group of cases has recently been reported in 3 which a ketogenic diet precipitated fasting hypo- $\vec{N}$ glycaemia (Colle and Ulstrom, 1964). Emotional stress may be a precipitating factor in some of these children.

Symptomatic hypoglycaemia in the newborn is

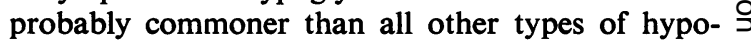
glycaemia in childhood. The non-specific nature of hypoglycaemic symptoms in the newborn and the $\mathscr{D}$ not infrequent discovery of very low blood sugar $\frac{}{\mathbb{O}}$ levels in well babies has led to slow acceptance of $\exists$ the role of neonatal hypoglycaemia in the causation of symptoms. The diagnosis depends on the demong stration that the administration of intravenous glucose, in the presence of a low blood glucoss rapidly abolishes the symptoms. Caution is needed in interpreting blood sugar levels in the newborn because more non-glucose reducing substances are present than in older children (Haworth, 1965) and because estimations on capillary blood may be lower than those on central venous blood, perhaps because peripheral stasis may permit more glycolysis (Stur, 1964).

Infants born to diabetic women often develop hypoglycaemia early after delivery and it can be shown that a glucose load disappears from their blood faster than in infants of healthy mothers (Baird and Farquhar, 1962). Administration of $0.13 \mathrm{U}$ soluble insulin per $\mathrm{kg}$. to normal infants makes their glucose tolerance approach that of those born to diabetics (Farquhar, 1965). The blood sugar returns quickly to normal in the diabetic mother's infant (Farquhar, 1956) and they may produce more insulin in response to a standard glucose load than $N$ normals (Baird and Farquhar, 1962). They may have a fourfold increase in pancreatic $\beta$-cells (Woolf and Jackson, 1957.)

Infants born to toxaemic mothers also seem especially likely to develop symptomatic hypoglycaemia, (Cornblath, Odell and Levin, 1959) and it is also apparent that other infants whose birth-weight is low for gestational age are also more 
likely to become hypoglycaemic. Male infants, and the smaller of twins are more likely to be affected. Hypoglycaemia is sometimes associated with hypocalcaemia and polycythaemia (Cornblath, Wybregt, Baens, and Klein, 1964). Although symptoms of neuroglycopenia are most likely to appear within the first forty-eight hours, treatment may need to be continued for several days, and late relapse may occasionally occur. A dysmature infant has recently been reported in whom hypoglycaemia, which responded to corticosteroids and glucose, appeared on the second day of life. On the fifth day hyperglycaemia and glycosuria developed without ketoacidosis and treatment with insulin was required (Chance and Bower, 1966). The tendency to hypoglycaemia and the child's insulin requirements gradually diminished until treatment became unnecessary at the age of four months. Symptomatic hypoglycaemia may occur in neo-natal cold injury (Mann and Elliott, 1957) and the respiratory distress syndrome (Usher, 1961).

The mechanism of hypoglycaemia where there is no maternal diabetes is uncertain. Normal full term and premature infants may show a rather small response to glucagon and adrenaline (Cornblath, Ganzon, Nicolopoulos, Baens, Hollander, Gordon and Gordon, 1961; Cornblath, Wybregt, and Baens 1963). Those with symptomatic hypoglycaemia may show some degree of tolbutamide and leucine sensitivity (Cornblath and others, 1964), but such sensitivity is not normally marked in normal premature infants (Cornblath and others, 1963). There is no evidence of adrenal cortical deficiency and there is no clear correlation between blood glucose levels and growth hormone levels which tend to be higher than in older age groups (Cornblath, Parker, Reisner, Forbes, and Daughaday, 1965). It has been suggested that the large relative weight of the brain in the newborn in proportion to the weight of the liver may be responsible for exhaustion of available glycogen (Cornblath and others, 1963). In malnourished newborn the brain may be seven times the weight of the liver (Dawkins, 1963).

Gastro-intestinal bleeding and perforation of duodenal ulcers occurred in two babies who had hypoglycaemia in the first two months of life (Hathaway and Moore, 1963).

Electroencephalographic changes occur during neuroglycopenia (Haworth and Coodin, 1960), and cerebral cortical necrosis (Lawrence, Meyer and Nevin, 1942) and anterior horn cell degeneration have been noted (Tom and Richardson, 1951). Infantile spasms have been seen in an infant who previously had symptomatic hypoglycaemia (Millichap, Bickford, Klass and Backus, 1962). Conversely, there is some evidence that hydrocephalus and other central nervous lesions may be associated with hypoglycaemia, but a precise causal relationship is uncertain (Etheridge and Millichap, 1964).

Where hypoglycaemia forms part of a more complex syndrome it bears the prognosis of the major illness and may or may not require specific treatment other than that appropriate to the main disease. The prognosis of idiopathic cases is worse when symptoms begin before six months of age. Thus, in a series of fifty eight cases (Howarth and Coodin, 1960) twenty one were mentally retarded and seven died. Of those who developed symptoms before the sixth month fifty per cent were retarded, but in those who developed symptoms later, the incidence of retardation was only eight per cent. In neonatal hypoglycaemia the prognosis may be worse (Brown and Wallis, 1963).

In some mild idiopathic cases dietary modification to regular balanced food intake is adequate treatment, but others often require corticosteroids or ACTH (McQuarrie, 1954).

Resistant cases have responded to glucogen zinc (Kushner, Lemli and Smith, 1963) and human growth hormone (Soyka, Molliver and Crawford, 1964). Dietary restriction of leucine and carbohydrate supplements may be useful in leucine sensitive children, but this may need supporting with ephedrine or long acting adrenaline (Grieze and Wenzel, 1965). The degree of leucine restriction which can be achieved is limited by growth and metabolic requirements. Recently, diazoxide, a thiazide compound, has been successfully used to diminish leucine sensitivity (Drash and Wolff, 1964).

Acute attacks of hypoglycaemia are terminated by intravenous or oral glucose. In the newborn the former route is preferred and large amounts of glucose may be needed as well as corticosteroids. Provided glycolytic enzymes and the hepatic storage of glycogen are normal, injections of adrenaline and glucagon should restore the blood glucose level.

In apparently idiopathic cases which fail to respond or remit after two years medical treatment, exploration of the pancreas for a $\beta$-cell tumour may be indicated, and if negative partial pancreatectomy may be helpful (Haworth and Coodin, 1960).

\section{REFERENCES}

BaIRD, J. D., and FARQuhar, J. W. (1962): Insulin Secreting Capacity in the Newborn Infants of Normal and Diabetic Women. Lancet, i, 71.

Bennett, T. E., and TARAIL, R. (1961): The Hypoglycaemic Activity of 2-Amino 2-Hydroxy Methyl-1 3-Propanediol, Ann. N.Y. Acad. Sci. 92, 651.

Brasel, J. A., Wright, J. C., Wilkins, L., and BlizzARD, R. M. (1965): An Evaluation of Seventy Five Patients with Hypopituitarism Beginning in Childhood, Amer. J. Med., 38, 484. 
Broberger, O., and Zetterstrom, R. (1961): Hypoglycaemia with Inability to Increase the Epinephrine Secretion in Insulin Induced Hypoglycaemia, J. Pediat., 59, 215.

Broster, L. R., and Patterson, J. (1948): An Unusual Case of Adrenal Carcinoma, Brit. med. J. i, 781.

Brown, R. J. K., and WAllis, P. G. (1963): Hypoglycaemia in the Newborn Infant, Lancet, $\mathbf{i}, 1278$.

Chance, G. W., and Bower, B. D. (1966): Hypoglycaemia and Temporary Hyperglycaemia in Infants of Low Birth Weight for Maturity, Arch. dis. Childh., 41, 279.

Christensen, L. K., Hansen, J. M., Kristensen, M. (1963): Sulphaphenazole Induced Hypoglycaemia Attacks in Tolbutamide Diabetics, Lancet, ii, 1298.

Cochrane, W. A., Payne, W. W., Simkiss, M. J., and Woolf, L. I. (1956): Familial Hypoglycaemia Precipitated by Amino Acids, J. clin. Invest., 35, 411.

Cleveland, W. W., Green, O. C., and Migeon, C. J. (1960): A Case of Proved Adrenocorticotrophn Deficiency, J. Pediat., 57, 376.

Colle, E., and Ulstrom, R. A. (1964): Ketotic Hypoglycaemia, J. Pediat., 64, 632.

CoOPER, A. J., and KedDie, K. M. G. (1964): Hypotensive Collapse and Hypoglycaemia After Mebanazine-a Monoamine Oxidase Inhibitor, Lancet, i, 1133.

Cornblath, M., Odell, G. B., and Levin, E. Y. (1959): Symptomatic Neonatal Hypoglycaemia Associated with Toxaemia of Pregnancy, J. Pediat., 55, 545.

Cornblath, M., Gazon, A. F., Nicolopoulos, D., Baens, G. S., Hollander, R. J., Gordon, M. H., and Gordon, H. H. (1961): Studies in Carbohydrate Metabolism in the Newborn Infant (3). Some Factors Influencing Capillary Blood Sugar and the Response to Glucagon During the First Hours of Life, Pediat, 27, 378.

Cornblath, M., Wybregt, S. H., and Baens, G. S. (1963): Studies in Carbohydrate Metabolism in the Newborn (7). Tests of Carbohydrate Tolerance in Premature Infants, Pediat., 32, 1007.

Cornblath, M., Wybregt, S. H., Baens, G. S., and KLEIN, R. I. (1964): Studies in Carbohydrate Metabolism in the Newborn (8). Symptomatic Neonatal Hypoglycaemia, Pediat., 33, 388.

Cornblath, M., Parker, M. L., Reisner, S. H., Forbes, A. E., and DaughadaY, W. H. (1965): The Secretion and Metabolism of Growth Hormone in Premature and Full Term Infants, J. clin. Endocr., 25, 209.

Cotton, E. K., and FahlberG, V. I. (1964): Hypoglycaemia with Salicylate Poisoning, Amer. J. dis. Childh., 108, 171.

Cummins, L. H. (1961): Hypoglycaemia and Convulsions in Children following Alcohol Ingestion,J.Pediat., 58, 23.

Cunningham, G. C. (1964): Tolbutamide Tolerance in Hypoglycaemic Children, Amer.J. dis. Childh., 107, 417.

DANIEL, W. A. (1941): A Study of Insulin Tolerance and Glucose Tolerance Tests in Normal Infants, J. Pediat., 19, 789.

DAwkins, M. J. R. (1963): Foetal and Infant Liver Function and Structure, Ann. N.Y. Acad. Sci., 11, 538.

Di George, A. M., and Auerbach, V. H. (1960): Leucine Induced Hypoglycaemia. A Review and Speculations, Amer. J. med. Sci., 240, 792.

Di George, A. M., Auerbach, V. H., and Mabry, C. C. (1963): Leucine Induced Hypoglycaemia (3). The Blood Glucose Depressant Action of Leucine in Normal Individuals, J. Pediat., 63, 295.

Dodge, P. R., Mancall, E. L., Crawford, J. D., KNAPP, J., and PAINE, R. S. (1959): Hypoglycaemia Complicating the Treatment of Phenylketonuria with a Phenylalanine Deficient Diet, New Engl. J. Med., 260, 1104.
Drash, A., and Woolf, F. (1964): Drug Therapy in Leucine Sensitive Hypoglycaemia, Metabolism, 13, 487.

Elliott, R. I. K., MANN, T. P., and NASH, F. W. (1962): Liver Disease in Infancy, Postgrad. med. J., 38, 642.

EMERY, J. L. (1947): Cold Sweating, Hypoglycaemia and Carbohydrate Insufficiency with Particular Reference to Coeliac Disease, Arch. Dis. Childh., 22, 34.

ETheridge, J. E., and Millichap, J. G. (1964): Hypoglycaemia and Seizures in Childhood, Neurology (Minneap), 14, 397.

Fajans, S. S., Schneider, J. M., Schteingart, D. E. and ConN, J. W. (1961): The Diagnostic Value of Sodium Tolbutamide in Hypoglycaemic States, J. clin. Endocr., 21, 371.

FARQUHAR, J. W. (1956): Significance of Hypoglycaemia in the Newborn Infant of the Diabetic Woman, Arch. dis. Childh., 31, 203.

FARQUHAR, J. W. (1965): in Recent Advances in Paediatrics, Ed. D. Gairdner. London: J. \& A. Churchill.

Folin, O., and WU, H. (1920): A System of Blocd Analysis. Supplement (1), A Simplified and Improved Method of Determination of Sugar, J. biol. Chem., 41, 367.

Francois, R. Pradon, M., Sherrer, M., and Ugliengo, A. R. (1962): Hypoglycaemia Due to Pancreatic Islet Cell Adenoma, J. Pediat., 60, 721.

Frazer, R., Albright, F., and Smith, P. H. (1941): The Value of the Glucose Tolerance Test, the Insulin Tolerance Test and the Glucose Insulin Tolerance Test in the Diagnosis of Endocrine Disorders of Carbohydrate Metabolism, J. clin. Endocr., 1, 297.

Gaultier, M., Fournier, F., Gervais., P., Frejaville, J. P., and Prier, F. (1962): Cinq can d'intoxication par l'amanite phalloide, Bull. Soc. med. Hop. Paris, 113 967.

GePPert, L. J., Spencer, W. A., and Richmond, A. M (1950): Adrenal Insufficiency in Infancy, J. Pediat $37,1$.

Greenblath, R. B., and Kupperman, H. S. (1947)! Diagnostic Value of Glucose Tolerance and Insulin Tolerance Tests in Endocrine Disorders, Sth. med. J., 40, 737 .

Griese, G. G., and Wenzel, F. J. (1965): Leucine Sensitive Hypoglycaemia Treated with Long Acting Epinephrine, Pediat., 35, 709.

Gutman, A., and LefFkowitz, M. (1959): Tuberous Sclerosis Associated with Spontaneous Hypoglycaemia, Brit. med., ii, 1065.

HAgedorn, H. C., and Jensen, B. N. (1923): Zur Mikrobestimmung des Blutzuckers Mittels Ferricyanid, Biochem. Z., 135, 46.

Hathaway, W. E., and Moore, T. C. (1963): Hypoglycaemia and Perforated Peptic Ulcer in Infancy, Clin. Pediat., 2, 425.

Haworth, J. C., and Coodin, F. J. (1960): Idiopathic Spontaneous Hypoglycaemia in Children, Pediat., 25, 748.

HAwORTH, J. C. (1965): Carbohydrate Metabolism in the Fetus and the Newborn, Pediat. Clin. N. Amer., 12, 573.

Hers, H. G. (1964): Glycogen Storage Disease, Advanc. metabol. Dis., 1, 1.

Hill, K. R. (1952): Vomiting Sickness of Jamaica, $W$. Indian med. J., 1, 243.

Howard, J. E. (1955): Differential Diagnosis and Therapy of Spontaneous Hypoglycaemia, Veterans Adm. med. Bull., 8, 1.

Howard, J. E., and DAvis, P. L. (1959): Retroperitoneal Hemangiopericytoma Associated with Hypoglycaemia and Masculinisation, Delaware med. J., 31, 29. 
Hruban, Z., Schulman, S., Warne, N. E., Dubois, K. P., Bunnag, S., and Bunnag, S. C. (1963): Hypoglycaemia Resulting from Insecticide Poisoning, $J$. Amer. med. Ass., 184, 590.

Hurez, A., Bedouelle, J., Debray, H., Le Bras, A., Halle, B. (1961): Carcinome Langerhansien Avec Manifestations Hypoglycaemiques Severes Chez un Enfant de 9 ans - Pancreatectomie Partielle, Arch. franc. Pediat., 18, 625.

ILEFNGWORTH, B., CORI, G. T., and CoRI, C. F. (1956): Amylo-1, 6-Glucosidase, in Muscle Tissue in Generalised Glycogen Storage Disease, J. biol. Chem., 218, 123.

JARRETT, R. J., and BUTTERFIELD, W. J. H. (1964): Leucine Induced Hypoglycaemia and Oral Hypoglycaemic Drugs, Brit. med. J., i, 865.

JeANNIN, J. (1960): Grave Hypoglycaemic State Appearing During Measles, Minerva Pediat., 12, 963.

KInSBOURNe, M., and Woolf, L. I. (1959): Idiopathic Infantile Hypoglycaemia, Arch. Dis. Childh., 34, 166.

Komrower, G. M., Schwarz, V., Holzel, A., and GoldBERG, L. (1956): A Clinical and Biochemical Study of Galactosaemia, Arch. Dis. Childh., 31, 254.

KuSHNER, R. S., LemLe, L., and SMITH, D. W. (1963): Zinc Glucagon in the Management of Hypoglycaemia, J. Pediat., 63, 1111.

Laron, Z. (1961): Essential Benign Fructosuria, Arch. Dis. Childh., 36, 272.

LaWrence, R. D., Meyer, A., and Nevin, S. (1942): Pathological Changes in the Brain in Fatal Hypoglycaemia, Quart. J. Med., 11, 181.

LeVIN, B., Oberholzer, V. G., SNOdgrass, G. J. A. I., StIMMLER, L., and Wilmers, M. J. (1963): Fructosaemia, Arch. Dis. Childh., 38, 220.

Lewis, G. M., Spencer-Peet, J., and Stewart, K. M. (1963): Infantile Hypoglycaemia Due to Inherited Deficiency of Glycogen Synthetase, in the Liver, Arch. Dis. Childh., 38, 40.

Limbeck, G. A., Ruvalcaba, R. H. A., SAmols, E., and KELLEY, V. C. (1965): Salicylates and Hypoglycaemia, Amer. J. Dis. Childh., 109, 165.

LloYd, J. K. (1964): Diabetes Mellitus Presenting as Spontaneous Hypoglycaemia in Childhood, Proc. roy. Soc. Med., 57, 1061.

Loutfi, A. H., Mehrez, I., ShaHbender, S., and Abdine, F. H. (1964): Hypoglycaemia with Wilms's Tunour, Arch. Dis. Childh., 39, 197.

Mabry, C. C., Di George, A. M., and Auerbach, V. H. (1960 a): Leucine Induced Hypoglycaemia (1) Clinical Observations and Diagnostic Considerations, J. Pediat., 57, 526.

Mabry, C. C., Di George, A. M., and Auerbach, V. H. $(1960$ b) : Leucine Induced Hypoglycaemia (2) Studies Concerning Other Amino Acids and Leucine Metabolism, Ibid., 57, 539.

McC. Giles, H. (1965): Encephalopathy and Fatty Degeneration of the Viscera, Lancet, i, 1075.

McIntosh, R. (1927): Acute Phosphorus Poisoning. Report of a Case with Recovery, Amer.J. Dis. Childh., 34, 595.

MCQUARRIE, I. (1954): Idiopathic Spontaneously Occurring Hypoglycaemia in Infants, Amer. J. Dis. Childh., 87, 399.

MCQuARrie, I., Ulstrom, R. A., ZeIGleR, M. R., (1954): Random Notes Concerning the Etiological Mechanisms and Treatment of Spontaneous Hypoglycaemia, Acta. Pediat. suppl., 100, 481.

Magnusson, J. H. (1934): Contribution to the Knowledge of Acute Suprarenal Insufficiency in Children, Acta. paediat., 15, 396.

MaNN, T. P., and Elliotr, R. I. K. (1957): Neonatal Cold Injury Due to Accidental Exposure to Cold, Lancet, i, 229.
MANn, T. P. (1959 a): Recurrent Hypoglycaemia, Haematemesis and Ketonuria in Identical Twins, Proc. roy. Soc. Med., 52, 1023.

ManN, T. P. (1959 b): Chicken Pox Encephalitis with Hypoglycaemia, Proc. roy. Soc. Med., 52, 1028.

MARKS, V. (1959): An Improved Glucose Oxide Method of Determining Blood, C.S.F. and Urine Glucose Levels, Clin. chim. Acta., 4, 395.

Meltzer, L. E., Palmon, F. P., and Kitchell, J. R. (1961): Hypoglycaemia Induced by Disodium Ethylenediamine Tetraacetic Acid, Lancet, ii, 637.

MenKeS, J. H. (1964): Maple Syrup Disease and Other Rare Disorders of Aminoacid Metabolism, Clin. Proc. Child. Hosp. Dist. Columbia, 20, 153.

Merivale, W. H. H., and Hunter, R. A. (1954): Abnormal Glucose Tolerance Tests in Patients Treated with Sedative Drugs, Lancet, ii, 939.

Millichap, J. G., BickFoRD, R. G., Klass, D. W., and BACKUS, R. E. (1962): Infantile Spasms, Hypsarythmia and Mental Retardation. A Study of Aetiological Factors in 61 Patients, Epilepsia (Amst.), 3, 188.

Mortimer, E. A., and LePow, M. L. (1962): Varicella and Hypoglycaemia Possibly Due to Salicylates, Amer. J. Dis. Child., 103, 583.

NADER, P., and LeONARDS, R. (1965): Varicella and Hypoglycaemia with Recovery, Amer. J. Dis. Child., $110,678$.

Nadler, H. L., Neumann, L. L., and Gershberg, H. (1963): Hypoglycaemia, Growth Retardation and Probable Isolated Growth Hormone Deficiency in a 1 Year Old Child, J. Pediat., 63, 977.

Neligan, G. A., Robson, E., and Walton, J. (1963): Hypoglycaemia in the Newborn. A Sequel to Intrauterine Malnutrition, Lancet, i, 1282.

Odell, W. D., Green, G. M., and Williams ,R. H. (1960): Hypoadrenotropism - the Isolated Deficiency of Adrenotropic Hormone, J. clin. Endocr., 20, 1017.

Ollagnier, C., Perrin, L. F., Miraillet, P. (1959): Coma Hypoglycaemia an Cours d'un Traitement au P.A.S. Intraveineux, Lyon med., 201, 787.

Patrick, S. J., JelifFe, D. B., and StUart, K. L. (1955): The Hepatic Glycogen Content in Acute Toxic Hypoglycaemia, J. trop. Pediat., 1, 88.

Planchu, M., Bertoye, A., Piquet, G., and Bertrand, J. L. (1963): Hypoglycemie au Cours d'un Traitement Prolonge et Intraveineux par la Methicillin, Lyon med., 210, 477.

Rector, J. M., and Jennings, R. E. (1937): Functional Hypoglycaemia of Childhood, Amer.J. Dis. Child., 53, 1012.

Reye, R. D. K., Morgan, G., and Barail, J. (1963:) Encephalopathy and Fatty Degeneration of the Viscera. A Disease Entity in Childhood, Lancet, ii, 749.

Ross, S. G., and JosePHS, H. W. (1924): Observations on the Metabolism of Recurrent Vomiting, Amer. J. Dis. Child., 28, 447.

Roth, J., Glick, S. M., Yalow, R. S., and Berson, S. A. (1963): Hypoglycaemia. A Potent Stimulus to the Secretion of Growth Hormone, Science, 140, 987.

Roxburgh, R. C. (1954): Islet Cell Adenoma of the Pancreas in a Child Aged 7 Years, Lancet, i, 1057.

Rubenstein, A. H., Levin, N. W., and Elliott, G. A. (1962): Manganese Induced Hypoglycaemia, Lancet, ii, 1349.

SAmols, E. (1963): Hypoglycaemia in Neoplasia, Postgrad. med. J., 39, 634.

Samols, E., and Marks, V. (1963): Insulin Assay in Insulinomas, Brit. med. J., i, 507.

SIDBURY, J. B. (1957): The Enzymatic Lesions in Galactosaemia, J. clin. Investig., 36, 929. 
Sidbury, J. B., Cornblath, M. Fisher, J., and House, H. (1961): Glycogen in Erythrocytes in Patients with Glycogen Storage Disease, Pediatrics, 27, 103.

SomoGyI, M. (1952): Notes on Sugar Determination, J. biol. Chem., 195, 9.

Soyka, L. F., Molliver, M., and Crawford, J. D. (1964): Idiopathic Hypoglycaemia of Infancy Treated with Human Growth Hormone, Lancet, i, 1015.

Stuart, K. L., Jeliffe, D. B., and Hill, K. R. (1955): Acute Toxic Hypoglycaemia occuring in the Vomiting Sickness of Jamaica, J. trop. Pediat., 1, 69.

Stur, O. (1964): Studies on the Physiological Hypoglycaemia of Newborns, Biol. Neonat. (Basel), 6, 38.

Talbot, F. B., Shaw, E. B., and Moriarty, M. E. (1924): Hypoglycaemia nad Acidosis, J. Amer. med. Ass., 83, 91 .

TARAIL, R., and BennetT, T. E. (1959): Hypoglycaemic Activity of Tris Buffer in Man and Dog, Proc. Soc. exp. Biol. (N. Y.), 102, 208.

Tous, A. D. (1965): Hypoglycaemic Convulsions in Children following Alcohol Ingestion, Pediat. Clin. N. Amer., 12, 423.

ToM, M. I., and Richardson, J. C. (1951): Hypoglycaemia from Islet Cell Tumour of the Pancreas with Amyotrophy and Cerebrospinal Nerve Cell Changes, J. Neuropath. exp. Neurol., 10, 57.

TomLInson, B. E. (1955): Fatal Hypoglycaemia in Early Non-Icteric Infective Hepatitis Lancet, i, 1300.
Underwood, L. E., and JACOBS, N. M. (1963): Familial Endocrine Adenomatosis. A Family with Hyperinsulinism as the Predominant Manifestation, Amer.J. Dis. Child., 106, 218.

Usher, R. H. (1961): The Metabolic Changes in the Respiratory Distress Syndrome of Prematurity seen as a Failure of Somatic Compensation for Asphxyia. In Somatic Stability in the Newborn. CIBA Foundation Symposium edited by G. E. W. Wolstenholme and M. O'Connor. London: J. \& A. Churchill p. 97.

WAYBuRne, S. (1963): Hepatic Failure in Malnutrition, Lancet, i, 447.

White, F. P., and Sutron, L. E. (1951): Adrenogenital Syndrome Associated with Episodes of Hypoglycaemia, J. clin. Endocr., 11, 1395.

Williams, A., and Robinson, M. J. (1956): Addison's Disease in Infancy, Arch. Dis. Childh., 31, 265.

Woolf, L. I. (1962): Inherited Metabolic Disorders: Galactosaemia, Advanc. clin. Chem., 5, 1.

Woolf, N., and JAckson, W. P. U. (1957): Maternal Prediabetes and the Foetal Pancreas, J. Path. Bact., 74, 223.

Wybregt, S. H., Reisner, S. H., Patel, R. K., Nellhaus, G., and Cornblath, M. (1964): The Incidence of Neonatal Hypoglycaemia in a Nursery for Premature Infants, J. Pediat., 64, 796. 